\title{
EXPANDING THE PROFESSIONAL PEDAGOGICAL PROFILE OF TEACHER FROM PROFESSIONAL (VOCATIONAL) EDUCATION SCHOOL UNDER THE CONDITIONS OF INCLUSION
}

\author{
Nataliia Sysko \\ Candidate of Psychological Sciences (Ph.D), Head of the Laboratory for Advanced Training and Experimental Work \\ of the Scientific and Methodical Center of Vocational Education and Training of Engineering and Pedagogical Workers in Khmel- \\ nitsky Oblast \\ http://orcid.org/0000-0001-7665-8325, e-mail: nnsysko@ukr.net
}

\section{Abstract.}

Relevance: persons with special educational needs require professional qualifications. This leads to the actualization of the issue of expanding the professional and pedagogical profile of the teacher of the P(V) E school and the inclusive competence acquisition.

Aim: to analyze the legal documents on the provision of inclusive education in the system of vocational education and training and study the needs of teachers of $\mathrm{P}(\mathrm{V}) \mathrm{E}$ school in the formation of inclusive competence.

Methods: theoretical (analysis, synthesis, generalization); empirical (interviewing methods, conversation).

Results: it has been found out that the problem of expanding the professional and pedagogical profile of the teacher of the professional (vocational) education school in the direction of his inclusive competence development needs to be addressed. It has been established that the creation of the barrier-free educational environment and the architectural accessibility of facilities in educational institutions for education applicants with special educational needs is necessary. The vast majority of teachers require the specially organized training on issues of inclusion introduction. It has been defined that teachers identify such forms of increasing the inclusive competence as training, specialist counseling and full-time targeted courses. The experience of forming the inclusive competence of teachers through the introduction of formal, non-formal and informal education has been presented. It has been stated that it is important to establish cooperation between educational institutions and regional inclusive resource centers. It has been proved that teachers need assistance in developing an individual curriculum for the education applicants with special educational needs and evaluation of its implementation.

Conclusions: the introduction of inclusive education in the system of vocational education and training will give the opportunity to obtain the working qualification for persons with disabilities, which will facilitate their personal and professional development; successful implementation of this task requires the expansion of the professional and pedagogical profile of the teacher of the professional (vocational) education school in the direction of inclusion, the creation of an inclusive educational environment, the introduction of appropriate pedagogical technologies, the development of training programs and their didactic support.

Keywords: teacher of the professional (vocational) education school; professional development; professional and pedagogical profile; competence; inclusion.

Introduction. At the present stage of development of the educational system, and, in particular, the professional (vocational) one, the basic principles of the Law of Ukraine "On Education" (2017) are: human-centrism, the rule of law, ensuring the quality of education and educational activity, the development of inclusive environment, humanism, democracy, accessibility for all citizens of all forms and types of educational services.

It should be noted that in Ukraine there are 167 thousand children with disabilities, representing $2 \%$ of the total population in this age category. At the same time, only $4 \%$ of children are enrolled in inclusive education, although disability should not be an obsta- 
cle to personal and professional self-realization of the individual (Ministry of Social Policy of Ukraine, 2013).

Inclusive education is an integral part of the humanitarian policy of every modern country and a testament to society's willingness to realize the inalienable human rights to education and lifelong learning (Ministry of Social Policy of Ukraine, 2019). In connection with the introduction of inclusive education, the adoption of the Procedure for the organization of inclusive education in the professional (vocational) education schools, it is necessary to form the competence of teachers to teach persons with special educational needs (Verkhovna Rada of Ukraine. Legislation of Ukraine, 2019).

Therefore, it is urgent to expand the professional and pedagogical profile of the teacher of $\mathrm{P}(\mathrm{V}) \mathrm{E}$ school (Sysko, 2019) and acquire inclusive competence.

Sources of research. The Law of Ukraine "On Education" (2017) treats the concept of "competence" as "a dynamic combination of knowledge, skills, ways of thinking, attitudes, values and other personal qualities that determine the person's ability to socialize successfully, pursue a professional and/or further educational activity".

The term "inclusion" (translated from English inclusion, integration) proclaims the idea of comprehensive integration of people with special educational needs into society.

The ideology of inclusion is aimed at providing every person with educational opportunities, including professional ones, directly in educational institutions, providing students with special educational needs, the access to qualitative learning in the common educational environment, their socialization and further employment.

The implementation of the ideology of inclusive education requires a certain strategy to create an inclusive society, improve educational structures, systems and teaching methods to meet the educational needs of the individual. In the inclusive environment, every individual, especially with special educational needs, should feel safe and have a sense of belonging to the team, society.

In Ukraine, the development of inclusive education is at an early stage. At present, the inclusion rate in Ukraine is only $7 \%$, while in Italy $-99 \%$, Lithuania $-90 \%$, Norway --90\%, Hungary $-57 \%$, Slovakia $42 \%$, France $-25 \%$. Therefore, there is a problem of speeding up the implementation of European standards in the education of our country.

The Law of Ukraine “On Education” (2017) defines inclusive education as "a prerequisite for equal access to education for all education applicants". In Ukraine, the "Procedure for the organizing the inclusive education in secondary schools" was approved in 2011. In 2018/2019 11,866 students with special educational needs were educated with inclusive classes (Ministry of Education and Science of Ukraine, 2019d).

In order to introduce inclusion in the process of obtaining professional qualifications and competences, in 2019 at the state level, the Cabinet of Ministers of Ukraine adopted a decree approving the "Procedure for organizing the inclusive education in professional (vocational) education school". It, objectively, determines the need for improvement of conditions of organization of the educational process, its content, methods, teaching aids and provision of appropriate training of teaching staff for the implementation of inclusive education for education applicants with special educational needs.

It should be noted that in Ukraine and, even in previous years, the provision of vocational education to persons with disabilities in different educational establishments of different levels was practiced, but these were isolated examples that did not become widespread and functioned without sufficient legal support for inclusion.

While solving the problem of inclusion at the state level, a number of normative-legal documents was adopted, namely: the Law of Ukraine "On Education" (2017), in particular Article 19 "Education of Persons with Special Educational Needs" and Article 20 "Inclusive Education"; Law of Ukraine "On Amendments to Certain Laws of Ukraine on Access to Educational Services for Persons with Special Educational Needs" (2018); a resolution of the Cabinet of Ministers of Ukraine "On Amendments to the Procedure for Organizing Inclusive Education in Secondary Schools" (2017); decree of the Cabinet of Ministers of Ukraine "On the National Strategy for Reforming the Institutional Care and Children Upbringing System for 20172026 and a Plan of Measures for the Implementation of its First Stage" (2017); Decree of the Cabinet of Ministers of Ukraine "On Approval of the Regulations on Inclusive Resource Center" (2017); resolution of the Cabinet of Ministers of Ukraine "On Approval of the Procedure for Organizing Inclusive Education in Professional (Vocational) Education School" (2019).

The purpose of the paper is to analyze the normative-legal acts on providing inclusive training in the system of professional (vocational) education and study the needs of teachers of $\mathrm{P}(\mathrm{V}) \mathrm{E}$ schools in forming inclusive competence.

Methods: analysis and synthesis - to find out the state and level of development of the studied problem; diagnostic (questionnaire, conversation) - to study the need for teachers to develop inclusive competence; generalization - to formulate conclusions and recommendations for developing the competence of teaching staff in inclusive education implementation. 
Results and discussion. The Law of Ukraine "On Education" (2017) defines "inclusive learning" as "a system of state-guaranteed educational services based on the principles of non-discrimination, consideration of multilateral human activity, effective involvement and inclusion of all its participants in the educational process". The Law of Ukraine stipulates that "inclusive professional (vocational) education is a system of educational services for acquiring a profession or professional skills for persons with special educational needs guaranteed by the state" (Verkhovna Rada of Ukraine. Legislation of Ukraine, 2018). In order to exercise the rights of persons with special educational needs for qualitative vocational education, taking into account their opportunities and needs in Ukraine, a resolution of the Cabinet of Ministers of Ukraine "On Approval of the Procedure for Organizing Inclusive Training in professional (vocational) education schools" was adopted (Verkhovna Rada of Ukraine, Legislation of Ukraine, 2011).

At the same time, the legal framework is being expanded to provide and standardize inclusive education at the legislative level, in particular, letters of the Ministry of Education and Science of Ukraine № $1 /$ 9-498 dated 05.08.2019 "Methodological Recommendations for Organizing the Training of Persons with Special Educational Needs in Educational Institutions in 2019/2020 and No. 1/9-462 of 18/07/2019 "On Priority Areas of Psychological Service Work in the Education System for 2019/2020"

It should be noted that persons with special educational needs (who are not contraindicated in training in their chosen profession) are admitted to studying in professional (vocational) education schools. Teaching of students with special educational needs should take place using the types and forms of education that take into account their needs and individual abilities, personally oriented teaching methods.

In this regard, in order to organize the qualitative educational process for education applicants with special educational needs, an inclusive educational environment should be created in the $\mathrm{P}(\mathrm{V}) \mathrm{E}$ schools and psychological and pedagogical support of this category of students should be provided. The Law of Ukraine "On Education" (2017) emphasizes that "an inclusive educational environment in an educational institution is formed by a set of conditions, methods and means of their implementation for joint learning, education and development of the education applicants, taking into account their needs and opportunities".

The problem of the development of inclusive competence of teachers has been the subject of research by O. Kazachiner (2018), M. Chaikovskyi (2012); there are works devoted to inclusive education in the conditions of the vocational school (Pashchenko et al., 2011; Pashchenko, Hritsenok and Sofii, 2012),
N. Sysko (2018). At the same time, there is currently insufficient scientific research on the formation of inclusive competence among teachers of the system of professional (vocational) education.

It should be emphasized that in order to implement a qualitative inclusive learning in the professional (vocational) education schools, a barrier-free educational environment should be created and the architectural accessibility of the institution should be ensured. The interaction between the members of the team of psychological and pedagogical support should be well-organized and the competence of the teachers for the implementation of the differentiated approach to the educational problem development, assessments and quality control of knowledge of students with special educational needs should be formed.

In this context, the National Report on the State and Prospects for the Development of Education of Ukraine emphasizes the "need to increase the professional level of teaching staff by providing qualitatively new professional training and retraining, taking into account modern approaches and technologies of training and support of persons with special needs' (Kremen, 2016).

In order to study the state of inclusive education implementation in professional (vocational) education schools and the need to develop inclusive competence of pedagogical workers, an anonymous survey was conducted, which involved 90 teachers of $\mathrm{P}(\mathrm{V}) \mathrm{E}$ schools in Ukraine.

The majority of the participants of the research, assessing the state of creation of the barrier-free educational environment and the architectural accessibility of the placement in the educational institution (where they carry out pedagogical activity), noted that it needed improvement. Only $3.33 \%$ of teachers said that the whole territory and placement of the institution were accessible to students with special educational needs (hereinafter - students with SEN).

It turned out that $15.5 \%$ of teachers did not understand the essence of the concept of "inclusive learning", considering it to be the education of students with SEN in specialized educational institutions or specialized groups. $22.2 \%$ of the survey participants are not familiar with the approval "Procedure for organizing the inclusive education in professional (vocational) education schools", which indicates that teachers are not sufficiently informed and aware of this problem. And although $42.2 \%$ of the teachers of professional (vocational) education schools had some practical experience in teaching students with SEN, The analysis of the results of the questionnaire makes it possible to conclude that teachers need inclusive competence formation. 
Regarding the inclusive teaching methodology, only $33.3 \%$ of teachers indicate that they use a personal-oriented teaching method for students with SEN; $25,6 \%$ - the method of differentiated approach to the development of educational programs, assessment and quality control of knowledge of students with SEN; $17,8 \%$ - the method of development of the individual curriculum for the education applicant with SEN; 44,4\% - the method of organizing the individual consultations for students with SEN; 58.9\% of teachers use methods of interaction with parents of the student with SEN.

The vast majority of teachers $(86.7 \%)$ require specially organized training on the implementation of inclusion in $\mathrm{P}(\mathrm{V}) \mathrm{E}$ schools.

The results of the research of the teachers of $\mathrm{P}(\mathrm{V})$ E schools on the forms of inclusive competence development are presented in Table 1.

Therefore, the teachers have identified trainings, consultations and full-time targeted courses as the most appropriate forms of inclusive competence enhancement.

With the aim of forming the inclusive competence of teachers of $\mathrm{P}(\mathrm{V}) \mathrm{E}$ schools within the framework of formal education at the advanced training courses held by the Scientific and Methodological Center of Vocational Education and Training of Engineering Pedagogical Workers in Khmelnitsky region, the issue of providing inclusive education of $\mathrm{P}(\mathrm{V}) \mathrm{E}$ schools was introduced into the subject area.

At the level of non-formal education, training seminars, seminars-trainings, professional consultations with the staff of the regional resource center on support of inclusive education and regional inclusive-resource centers are held. Also, teachers of $\mathrm{P}(\mathrm{V})$ E schools as members of the team of psychological and pedagogical support of organizing the inclusive training, receive methodical assistance on the organization of educational process in the educational institution and training the education applicants with special educational needs in the Scientific and Methodological Center of Vocational Education and
Advanced Training of Engineering and Pedagogical Workers in Khmelnytsky Oblast.

The "Inclusive Learning" section has been created at the Information Portal "Vocational Education of Khmelnytsky Region", which is saturated with regulatory and scientific and methodological materials. It allows to move quickly to the inclusive section of the site of the Ministry of Education and Science of Ukraine, the site of the Khmelnytsky Regional Resource Center for Support of Inclusive Education.

It is worth to note that the acquisition and improvement of the competence of teachers in the provision of inclusive education will be facilitated by the well-established cooperation between the $\mathrm{P}(\mathrm{V}) \mathrm{E}$ schools and the Inclusive Resource Center (IRC), an institution established to exercise the rights of children with special educational needs from the age of 2 to 18 for obtaining education, including professional (vocational) one, by conducting a comprehensive psychological and pedagogical assessment of the child's development, providing psychological and pedagogical, correctional and developmental services and ensuring their systematic qualified support (Verkhovna Rada of Ukraine. Legislation of Ukraine, 2017).

By April 2019, 557 inclusive resource centers have been registered in Ukraine (MES of Ukraine website). A number of tasks performed by these institutions are to provide advice and interaction with the teaching staff of $\mathrm{P}(\mathrm{V}) \mathrm{E}$ schools on issues of inclusive education organization.

At the same time, teachers need assistance in issues of developing an individual curriculum for the education applicant with special educational needs and evaluation of its implementation.

It is necessary to resolve the issue of introducing a teaching assistant to the staff, who is involved in the development and implementation of the individual curriculum for the student with SEN, and also provides adaptation of educational materials taking into account the individual characteristics of educational and cognitive activity of the education applicant.

Conclusions. The introduction of inclusive ed-

Table 1

Results of the survey of the teachers of $P(V) E$ schools on forms of inclusive competence development

\begin{tabular}{llll} 
No & Form of education & Number of teachers who determined its expediency (\%) & Rank \\
\hline 1. & Full-time Targeted Courses & 43,3 & 3 \\
\hline 2. & Distance courses & 31,1 & 5 \\
3. & Lectures, seminars & 36,7 & 4 \\
4. & Trainings & 57,8 & 1 \\
5. & Counseling & 52,2 & 2 \\
\hline 6. & Round Table Meeting & 18,9 & 6 \\
\hline
\end{tabular}


ucation in the system of professional (vocational) education will provide an opportunity to obtain working qualifications for persons with disabilities, find a job and integrate themselves fully into public life. Successful accomplishment of this task requires the expansion of the professional and pedagogical profile of the teacher of $\mathrm{P}(\mathrm{V}) \mathrm{E}$ schools in the direction of inclusion, creation of the inclusive educational environment, introduction of appropriate pedagogical technologies, development of training programs and their didactic support.

\section{List of references}

Верховна Рада України. Законодавство України, 2011. Порядок організаиії інклюзивного навчання у загальноосвітніх навчальних закладах. [online] (Останнє оновлення 09 Серпень 2017) Доступно: <https://zakon.rada.gov.ua/ laws/show/872-2011-\%D0\%BF> [Дата звернення 15 Жовтень 2019].

Верховна Рада України. Законодавство України, 2017. Положення про інклюзивно-ресурсний центр. [online] (Останнє оновлення 22 Серпень 2018) Доступно:<https://zakon.rada.gov.ua/laws/show/545-2017-\%D0\%BF> [Дата звернення 19 Вересень 2019].

Верховна Рада України. Законодавство України, 2018. Закон України «Про внесення змін до деяких законів України щодо доступу осіб з особливими освітніми потребами до освітніх послуг» від 6 вересня 2018 року № 2541-VIII. [online] (Останнє оновлення 06 Вересень 2018) Доступно: <https://zakon.rada.gov.ua/laws/show/2541-19> [Дата звернення 25 Березень 2019].

Верховна Рада України. Законодавство України, 2019. Порядок організаиії інклюзивного навчання у закладах професійної (професійно-технічної) освіти. [online] (Останнє оновлення 25 Липень 2019) Доступно: <https://zakon. rada.gov.ua/laws/show/636-2019-\%D0\%BF > [Дата звернення 15 Жовтень 2019].

Казачінер, О.С., 2018 Теоретичні і методичні засади розвитку інклюзивної компетентності вчителів філологічних дисциплін у системі післядипломної освіти. Доктор наук. Хмельницький національний університет.

Кремень, В.Г. ред., 2016. Освіта дітей з особливими освітніми потребами. Національна доповідь про стан $i$ перспективи розвитку освіти в Україні. Київ: Педагогічна думка, с. 68-76.

Міністерство освіти і науки України, 2019. Інклюзивне навчання. [online] (Останнє оновлення 06 Жовтень 2019) Доступно: <http://profosvitakm.at.ua/index/inkljuzivne_navchannja/0-195> [Дата звернення 11 Жовтень 2019].

Міністерство освіти і науки України, 2019. Методичні рекомендації щодо організаиії навчання осіб з особливими освітніми потребами в закладах освіти в 2019/2020 н.p. [online] (Останнє оновлення 08 Серпень 2019) Доступно: $<$ https://mon.gov.ua/storage/app/media/inkluzyvne-navchannya/2019/08/07/rekomendatsiiorganizatsiya-navchannyaoop. pdf $>$ [Дата звернення 8 Серпень 2019].

Міністерство освіти і науки України, 2019. Про пріоритетні напрями роботи психологічної служби у системи освіти на 2019/2020 н.p. [online] (Останне оновлення 18 Липень 2019) Доступно: <https://mon.gov.ua/ua/npa/proprioritetni-napryami-roboti-psihologichnoyi-sluzhbi-u-sistemi-osviti-na-20192020-navchalnomu-roci> [Дата звернення 14 Серпень 2019].

Міністерство освіти і науки України, 2019. Статистичні дані. [online] (Останнє оновлення 18 Липень 2019) Доступно: <https://mon.gov.ua/storage/app/media/inkluzyvne-navchannya/statistika-inklyuziya.pdf $>$ [Дата звернення 17 Жовтень 2019].

Міністерство соціальної політики України, 2013. Про становище осіб з інвалідністю в Україні. Національна доповідь. [online], с. 7. (Останнє оновлення 18 Липень 2019) Доступно: file:///C:/Users/Volod/Downloads/REP0000749. PDF [Дата звернення 17 Жовтень 2019].

Міністерство соціальної політики України, 2019. Перша доповідь України про стан виконання Конвенції ООН про права осіб з інвалідністю. [online] (Останнє оновлення 29 Травень 2019) Доступно: https://www.msp.gov.ua/ timeline/Realizaciya-norm-Konvencii-pro-prava-osib-z-invalidnistyu.html [Дата звернення 17 Жовтень 2019].

Пащенко, О.В., Гриценок, І.А. та Софій, Н.3., 2012. Інклюзивна освіта в умовах професійно-технічного навчального закладу. Київ: АртЕкономі.

Пащенко, О.В., Гриценок, І.А., Софій, Н.3. та Найда, Ю.М., 2011. Індекс інклюзї̈: професійно-технічний навчальний заклад. Київ: ТОВ «Видавничий дім «Плеяди»». [online] Доступно: <http://elibrary.kubg.edu.ua/id/ eprint/5588/1/Y_Naida_IIPTNZ.pdf> [Дата звернення 12 Жовтень 2019].

Сиско, Н.М, 2018, Інклюзія в системі професійної (професійно-технічної) освіти. Професійна освіта: науково-методичний вісник, 1-2 (50-51), с. 64-71.

Сиско, Н.М., 2019. Проєктування професійно-педагогічного профілю викладача закладу професійної (професійно-технічної) освіти. Наукові записки Тернопільського національного педагогічного університету імені Володимира Гнатюка, 1, с.117-122.

Чайковський, М., 2012. Інклюзивна компетентність як складова компетентності суб'єктів навчально-виховного процесу. Педагогіка і психологія професійної освіти, [online] 2, с. 15-21. Доступно: <http://ena.lp.edu.ua/bitstream/ ntb/23642/1/4-15-21.pdf> [Дата звернення 12 Жовтень 2019].

Bazyl, L. O., Shatkovska, H. I., Klymenko, M. M., and Radkevych, V. O., 2019. Psychological and pedagogical features of the career growth of vocational education's teachers. Opcion, 35 (Special Issue 23), 763-779. 


\section{Translated \& Transliterated}

Verkhovna Rada Ukrainy. Zakonodavstvo Ukrainy [Verkhovna Rada of Ukraine. Legislation of Ukraine], 2011. Poriadok orhanizatsii inkliuzyvnoho navchannia u zahalnoosvitnikh navchalnykh zakladakh [Procedure for organizing the inclusive education in secondary schools.]. [online] (Ostannie onovlennia 09 Serpen 2017) Dostupno: <https://zakon.rada.gov.ua/ laws/show/872-2011-\%D0\%BF> [Data zvernennia 15 Zhovten 2019].

Verkhovna Rada Ukrainy. Zakonodavstvo Ukrainy [Verkhovna Rada of Ukraine. Legislation of Ukraine], 2017. Polozhennia pro inkliuzyvno-resursnyi tsentr [Regulations on Inclusive Resource Center]. [online] (Ostannie onovlennia 22 Serpen 2018) Dostupno:<https://zakon.rada.gov.ua/laws/show/545-2017-\%D0\%BF> [Data zvernennia 19 Veresen 2019].

Verkhovna Rada Ukrainy. Zakonodavstvo Ukrainy [Verkhovna Rada of Ukraine. Legislation of Ukraine], 2018. Zakon Ukrainy «Pro vnesennia zmin do deiakykh zakoniv Ukrainy shchodo dostupu osib z osoblyvymy osvitnimy potrebamy do osvitnikh posluh» vid 6 veresnia 2018 roku № 2541-VIII [Law of Ukraine «On Amendments to Certain Laws of Ukraine on Access to Educational Services for Persons with Special Educational Needs» of September 6, 2018 No. 2541-VIII.]. [online] (Ostannie onovlennia 06 Veresen 2018) Dostupno: < https://zakon.rada.gov.ua/laws/show/2541-19> [Data zvernennia 25 Berezen 2019].

Verkhovna Rada Ukrainy. Zakonodavstvo Ukrainy [Verkhovna Rada of Ukraine. Legislation of Ukraine], 2019. Poriadok orhanizatsii inkliuzyvnoho navchannia u zakladakh profesiinoi (profesiino-tekhnichnoi) osvity [Procedure for organizing the inclusive education in professional (vocational) education schools]. [online] (Ostannie onovlennia 25 Lypen 2019) Dostupno: <https://zakon.rada.gov.ua/laws/show/636-2019-\%D0\%BF > [Data zvernennia 15 Zhovten 2019].

Kazachiner, O.S., 2018 Teoretychni i metodychni zasady rozvytku inkliuzyvnoi kompetentnosti vchyteliv filolohichnykh dystsyplin u systemi pisliadyplomnoi osvity [Theoretical and methodological foundations of the development of inclusive competence of teachers of philological disciplines in the system of postgraduate education]. Doktor nauk. Khmelnytskyi natsionalnyi universytet.

Kremen, V.H. red., 2016. Osvita ditei z osoblyvymy osvitnimy potrebamy. Natsionalna dopovid pro stan i perspektyvy rozvytku osvity $v$ Ukraini [National report on the state and prospects of education development in Ukraine]. Kyiv: Pedahohichna dumka, s. 68-76.

Ministerstvo osvity i nauky nauky Ukrainy [Ministry of Education and Science of Ukraine], 2019a. Inkliuzyvne navchannia [Inclusive Education]. [online] (Ostannie onovlennia 06 Zhovten 2019) Dostupno: $<$ http://profosvitakm.at.ua/ index/inkljuzivne_navchannja/0-195> [Data zvernennia 11 Zhovten 2019].

Ministerstvo osvity i nauky Ukrainy [Ministry of Education and Science of Ukraine], 2019b. Metodychni rekomendatsii shchodo orhanizatsii navchannia osib z osoblyvymy osvitnimy potrebamy v zakladakh osvity v 2019/2020 n.r. [Methodical recommendations for the organization of training of persons with special educational needs in educational institutions in 2019/2020]. [online] (Ostannie onovlennia 08 Serpen 2019) Dostupno: $<$ https://mon.gov.ua/storage/app/media/inkluzyvnenavchannya/2019/08/07/rekomendatsiiorganizatsiya-navchannyaoop.pdf> [Data zvernennia 8 Serpen 2019].

Ministerstvo osvity i nauky Ukrainy [Ministry of Education and Science of Ukraine], 2019c. Pro priorytetni napriamy roboty psykholohichnoi sluzhby u systemy osvity na 2019/2020 n.r. [About priority directions of work of psychological service in educational systems for 2019/2020]. [online] (Ostannie onovlennia 18 Lypen 2019) Dostupno: <https://mon. gov.ua/ua/npa/pro-prioritetni-napryami-roboti-psihologichnoyi-sluzhbi-u-sistemi-osviti-na-20192020-navchalnomu-roci> [Data zvernennia 14 Serpen 2019].

Ministerstvo osvity i nauky Ukrainy [Ministry of Education and Science of Ukraine], 2019d. Statystychni dani [Statistical data]. [online] (Ostannie onovlennia 18 Lypen 2019) Dostupno: <https://mon.gov.ua/storage/app/media/inkluzyvnenavchannya/statistika-inklyuziya.pdf $>$ [Data zvernennia 17 Zhovten 2019].

Ministerstvo sotsialnoi polityky Ukrainy [Ministry of Social Policy of Ukraine], 2013. Pro stanovyshche osib z invalidnistiu v Ukraini. Natsionalna dopovid [On the situation of persons with disabilities in Ukraine. National report]. [online], s. 7. (Ostannie onovlennia 18 Lypen 2019) Dostupno: file:///C:/Users/Volod/Downloads/REP0000749.PDF [Data zvernennia 17 Zhovten 2019].

Ministerstvo sotsialnoi polityky Ukrainy [Ministry of Social Policy of Ukraine], 2019. Persha dopovid Ukrainy pro stan vykonannia Konventsii OON pro prava osib z invalidnistiu [The first report of Ukraine on the state of implementation of the UN Convention on the Rights of Persons with Disabilities]. [online] (Ostannie onovlennia 29 Traven 2019) Dostupno: https://www.msp.gov.ua/timeline/Realizaciya-norm-Konvencii-pro-prava-osib-z-invalidnistyu.html [Data zvernennia 17 Zhovten 2019].

Pashchenko, O.V., Hrytsenok, I. A. ta Sofii, N. Z., 2012. Inkliuzyvna osvita v umovakh profesiino-tekhnichnoho navchalnoho zakladu [Inclusive education in the conditions of vocational education and training institution]. Kyiv: ArtEkonomi.

Pashchenko, O.V., Hrytsenok, I.A., Sofii, N.Z. ta Naida, Yu.M., 2011. Indeks inkliuzii: profesiino-tekhnichnyi navchalnyi zaklad [Inclusion index: vocational education and training institution]. Kyiv: TOV «Vydavnychyi dim «Pleiady»». [online] Dostupno: <http://elibrary.kubg.edu.ua/id/eprint/5588/1/Y_Naida_IIPTNZ.pdf> [Data zvernennia 12 Zhovten 2019].

Sysko, N.M, 2018, Inkliuziia v systemi profesiinoi (profesiino-tekhnichnoi) osvity [Inclusion in Vocational Education.]. Profesiina osvita: naukovo-metodychnyi visnyk [Professional Education: Scientific and Methodological Bulletin], 1-2 (50-51), s. 64-71.

Sysko, N.M., 2019. Proiektuvannia profesiino-pedahohichnoho profiliu vykladacha zakladu profesiinoi (profesiinotekhnichnoi) osvity [Designing of the professional-pedagogical profile of the teacher of theprofessional (vocational) education school]. Naukovi zapysky Ternopilskoho natsionalnoho pedahohichnoho universytetu imeni Volodymyra Hnatiuka [Scientific Notes of the Ternopil National Pedagogical University named after Volodymyr Hnatyuk], 1, s. 117-122.

Chaikovskyi, M., 2012. Inkliuzyvna kompetentnist yak skladova kompetentnosti subiektiv navchalno-vykhovnoho protsesu [Inclusive competence as a component of the competence of subjects of educational process.]. Pedahohika $i$ psykholohiia profesiinoi osvity [Pedagogy and Psychology of Vocational Education], [online] 2, c. 15-21 Dostupno: <http:// ena.lp.edu.ua/bitstream/ntb/23642/1/4-15-21.pdf $>$ [Data zvernennia 12 Zhovten 2019]. 
Bazyl, L. O., Shatkovska, H. I., Klymenko, M. M., and Radkevych, V. O., 2019. Psychological and pedagogical features of the career growth of vocational education's teachers. Opcion, 35 (Special Issue 23), 763-779, [in English].

\section{Розширення професійно-педагогічного профілю викладача закладу професійної (професійно-технічної) освіти в умовах інклюзії}

\section{Наталія Сиско}

кандидат психологічних наук, завідувач лабораторії підвищення кваліфікації та дослідно-експериментальної роботи Науково-методичного центру професійно-технічної освіти та підвищення кваліфікації інженерно-педагогічних працівників у Хмельницькій області

\section{Реферат.}

Актуальність: особи з особливими освітніми потребами потребують здобуття професійних кваліфікацій. Це зумовлює актуалізацію питання розширення професійно-педагогічного профілю викладача ЗП(ПТ)О, набуття ним інклюзивної компетентності.

Meта: аналіз нормативно-правових документів щодо забезпечення інклюзивного навчання в системі професійної (професійно-технічної) освіти та дослідження потреби викладачів ЗП(ПТ)О у формуванні інклюзивної компетентності.

Методи: теоретичні (аналіз, синтез, узагальнення); емпіричні (анкетування, бесіда).

Результати: з'ясовано, що потребує вирішення проблема розширення професійно-педагогічного профілю викладача закладу професійної (професійно-технічної) освіти в напрямі розвитку його інклюзивної компетентності. Встановлено, що необхідним є створення безбар'єрного освітнього середовища та архітектурної доступності приміщень у закладі освіти для здобувачів освіти з особливими освітніми потребами. Переважна більшість викладачів потребує спеціально організованого навчання з питань запровадження інклюзії. Визначено, що викладачі виділяють такі форми підвищення інклюзивної компетентності, як: тренінги, консультування у фахівців та очні цільові курси. Представлено досвід формування інклюзивної компетентності педагогів шляхом упровадження формальної, неформальної та інформальної освіти. Констатовано, що важливим є налагодження співпраці між закладами освіти та регіональними інклюзивно-ресурсними центрами. Встановлено, що викладачі потребують допомоги в питаннях розробки індивідуального навчального плану здобувача освіти з особливими освітніми потребами та оцінки його виконання.

Висновки: запровадження інклюзивного навчання у системі професійної (професійно-технічної) освіти дасть змогу здобути робітничу кваліфікацію особам з інвалідністю, що сприятиме їхньому особистісному і професійному розвитку; успішна реалізація цього завдання потребує розширення професійно-педагогічного профілю викладачів ЗП(ПТ)О в напрямі інклюзії, створення інклюзивного освітнього середовища, запровадження відповідних педагогічних технологій, розроблення навчальних програм та їх дидактичного забезпечення.

Ключові слова: викладач закладу професійної (професійно-технічної) освіти; професійний розвиток; професійно-педагогічний профіль; компетентність; інклюзія. 